\title{
The Effect of Study Group Activity Guide in Expository Reading and Writing Course at the College of Architecture in Qassim University
}

\author{
Tomas U. Ganiron Jr \\ College of Architecture, Qassim University, Buraidah City \\ tomas@qec.edu.sa
}

\begin{abstract}
This research was conducted to assess the effectiveness of study group activity guide in Expository Reading and Writing Course at the College of Architecture. The experimental group used the study group activity guide method while the control group used the traditional lecture method.

Specifically, the study aimed to determine if by giving the architecture students ample time to answer guide questions and to interact with the other members of a particular group, with the teacher acting as a moderator, achievement in Expository Reading and Writing course can be improved.

Two classes of level 2 students enrolled at the College of Architecture-Qassim University, in Second Semester 2012-2013 were the samples of the study. Both groups were composed of thirty students each, with one group as the experimental and the other group as the control.

The study showed that that the experimental group which used the study group activity guide performed better as compared in the control group. This is attributed to better retention and learning among the architecture students in the experimental group because of several phases and types of learning experiences they were exposed.
\end{abstract}

Keywords: Classroom techniques, group activity guide, learning experiences, learning styles

\section{Introduction}

The assumptions underlying an andragogical approach to adult learning help to define the unique qualities of the adult learner [1]. As independent and self-directed beings, most adults are capable of assisting in the planning, execution and evaluation of their own learning activities. The adult's readiness and orientation to learning are a function of a developmental context different from that of a child. To a large extent, performing the roles and tasks inherent to adulthood determines what is to be learned, and results as well in immediate, rather than future, application of newly acquired knowledge. The necessity of dealing with the challenge inherent in adult living can form a basis for many adult education programs. Understanding the learning process itself also can enhance the practice of adult education.

Various principles of learning have been derived from controlled experiments with animals, children, and adults. Some of the research has not attempted to separate children from adult subjects and the findings are considered applicable to learners of any age. Other investigations have explored changes in learning ability as a function of age and have particular relevance to adult education. The contributions to knowledge about the learning process made by behaviorists, Gestalt psychologists, and cognitive theorists are applicable to both children and adults. 
The method that adults employ to learn a subject or skills vary greatly, presenting a sharp contrast to the relatively uniform techniques used in the schooling of young people. Methods that are employed almost widely solely in adult education include corresponding study, on-the-job training and short term conferences, institutes and workshops. Most adult, nonetheless, do learn in group settings and very often to a formal classroom environment.

At the University of Qassim, the educational system in the college is based on two main semesters per educational year. Each semester is fifteen (15) week length. In addition, an optional eight week summer semester may be offered. An architecture student may complete any of the architecture programs in 8 semesters after the Preparatory Year Program (PYP) [2, 3]. A successful architecture student may complete the full requirements of the selected program if he completed (after the PYP) a total of 139 credit-hours.

One of the basic courses in Architecture is Expository Reading and Writing. This course is a 3-unit subject offered in level 2 of winter semester. Expository Reading and Writing is the capstone course in basic architecture since it integrates almost all the knowledge a student has learned in 4 years of high school education. This course has traditionally been delivered through classroom multimedia instruction to architecture students. One semester learning period is insufficient to fully discuss all the topics for this course [4].

For a number of years, architecture students in Qassim University have been observed to have low achievements in English in terms of reading and writing. Some of the reasons given by the architecture students are lack of time, and the know-how in the process and approach to studying.

This study aimed to determine if by giving the architecture students ample time to answer guide questions and to get them to interact with other members of the group, with the teacher acting as moderator, achievement in Expository reading and Writing course could be improved.

\section{Related Literature}

For well over a decade, the focus of the university classroom has steadily shifted from a teaching-centric approach to a learning-centric approach [5]. This shift calls for a rethinking of the traditional classroom, replacing the standard lecture with a blend of pedagogical approaches that more regularly involve the student in the learning process.

Under a learning-centered approach, the instructor retains "control" of the classroom, but thought is regularly given to: (a) how well students will learn the material presented, and (b) the variety of pedagogically sound methods that may be employed to help the students better understand the core information to be learned.

\subsection{Questioning Techniques}

For those who use lecture as the primary delivery method in the classroom, there are a few relatively easy methods to increase student involvement and interest in the classroom, regardless of course level or academic field. At the simplest level, this approach requires asking questions during the lecture that challenge students to apply the concepts and principles introduced. Although most instructors would maintain that their students already ask questions during class, some college professors still devote only a small portion of class time to posing questions to students. Most of these questions are directed at the lowest cognitive level, requiring only recapitulation, 
clarification, or factual responses. Often only a small proportion of students regularly respond. There are a few things an instructor can do to increase the number of different students responding in a given class period. One method is simply to change the way in which questions are asked. Periodically calling on students is a long-held method to determine which students understand the material and which are paying attention. The only downside to this approach is that some students are terrified to speak before a group, and when surprised with a quickly-delivered question the student may "freeze". One approach that often helps students is to teach them to quickly sketch out a response to a question in their notes. When posing questions, pause for 15 to 30 seconds and then call on students. The length of the pause can be adjusted based on the cognitive complexity of the expected response. Another method is to give some "thinking" questions or calculations at the end of class and tell students the next class will begin with students being called on to respond to those items. Finally, it is sometimes helpful to focus attention on a small area of the class and wait for a response from a student volunteer. This increases "pressure" for someone in that area to respond.

In addition to getting a variety of students regularly responding to questions posed in the classroom, it is important that the responses increase in cognitive levels as the course progresses. To insure that they ask questions from the higher cognitive levels, or who are adept at questioning usually prepare for class by writing their questions in the margins of their lecture notes or on their lesson plan. Also keep in mind that, although there are many degrees of cognitive complexity, for planning purposes three levels are particularly important: remembering, applying, and evaluating [6].

2.1.1. Remembering Questions: At the lowest level, remembering questions help to ascertain whether the students have the facts straight-can they recall or recognize basic information.

2.1.2. Median Level Application Questions: Median level application questions require students to use information to: (a) deduce the significance of results of experiments, (b) apply formulas to new problems, (c) relate theoretical abstractions to real situations, or (d) analyze patterns of relationships among concepts and develop generalizations from them.

2.1.3. Evaluation Questions: Evaluation questions require students to exercise judgment-one of the higher levels of cognition. Students must choose the best alternatives or solutions and be able to justify those choices (in other words, to demonstrate the same thought processes that a professional in the field uses to make decisions).

The skillful use of probing and follow-up questions will encourage students to try to answer the more difficult and complex questions. Lectures in which students are regularly asked to respond hold additional benefits for learning. Students have the opportunity to test their understanding of the material as it is presented, they have many chances to practice thinking critically and creatively, and their motivation to study and keep up with course assignments improves [7,9].

Although a number of instructors report that they use questions to promote interaction even in very large classes, the method is clearly more difficult to use in larger sections. One approach that some instructors are using today involves audience response systems or "clickers." This technology allows the instructor to pose a question to the class and easily collect the responses. Advocates of this technological solution 
report that, when used in a learner-centered framework, the increased interaction through strategically posed questions can, among other things, assess prior knowledge; elicit a misperception; stimulate discussion; and exercise a cognitive skill [8,11]Many of the strategies described in this issue are complemented by audience response systems.

\subsection{Small Groups}

Research comparing the effectiveness of lectures and discussions indicates that, although both techniques are similarly effective for knowledge-level learning, the results consistently favor discussion methods over lecture on a number of measures: problem-solving, transfer of knowledge to new situations, and motivation for further learning [9]. There are many small group techniques that may be used in almost any course with very little effort or risk. The primary focus is getting students to really think about the material so they are able to vocalize what it is they are thinking about.

2.2.1. Pair Share: One of the easiest ways to get students talking about an issue or topic in class is to use the "think/write-pair-share" method [14]. In this approach, an instructor simply poses an issue or problem to the class and then gives students 30 seconds to one minute to think about or write out their response. Students then pair up and explain their responses to one another for 3 to 5 minutes. Finally, as a class, the issue or result is discussed. Because this technique takes only about 4 to 6 minutes of class time, it could be done one or two times in each class session. This format has worked successfully in many different kinds of courses including math, chemistry, history, philosophy, and art criticism. In a variation on the technique, the instructor asks students to vote on an issue (e.g., "Would you have voted to award President Obama the Nobel Peace Prize?"), and then asks individuals about what informed their decision. The class is asked to vote again, and students who changed their votes are asked why they did so [12].

2.2.2. Buzz Groups: This technique is used to ensure student participation in large classes [13]. In this lectures, teacher comes to a concept that lends itself to discussion, teacher asks students to form groups of five to eight people to talk about the issue. Teacher instructs them to make sure each member of the group contributes at least one idea to the discussion. After 10 minutes, teacher calls on some of the groups to report and asks other groups who came to the same conclusion to raise their hands. As they report, teacher records their main points on the blackboard and then incorporates the material into a future lecture.

2.2.3. Three-step Interview: For three step interview technique process, student first work in pairs $[14,15]$. The first person in the dyad conducts an interview or asks question to the second person. Similarly, the second person also conducts an interview or asks questions to the first person. For the next step, two dyads work together. One person from the first dyad explains their conclusion or summary to the second dyad, and one of the individuals from the second dyad explains their summary or results to the first dyad. 


\subsection{Whole Class Involvement}

2.3.1. Lecture Check: This strategy works very well in large classes, but effective in smaller class enrollments [16]. The first step is to deliver a lecture for 15 to 20 minutes, and then prepare a question for the class. Often, this is a multiple choice item that is similar to the type of question that will be used on an exam. Students are asked to raise their hands as the instructor asks how many think ' $a$ ' is the correct response, how many chose ' $b$ ', and so on. If most of the students have the correct response, the instructor simply continues with the course material. If, however, more than approximately $20 \%$ chose the incorrect response, the instructor has students turn to their neighbor and convince them of the correct choice. Finally, the instructor goes through the items again to see how many choose each alternative. If an unacceptable number still have incorrect responses, it may be wise to go back over the material. Students also can be called on to defend the selection they have made.

2.3.2. Whole Class Debates: Taking advantage of the dividing aisle in large lecture halls, the instructor assigns sides of a debate to the two halves of the class (or, by prearrangement, students sit on the side of the room representing the point of view they wish to support) [13]. The instructor asks each side for five statements supporting their side of the issue. This process may be repeated with rebuttals, until the instructor feels that the class has fully explored the issue. To end the debate and achieve closure, the instructor asks for two or three volunteers to make summary arguments for each side.

2.3.3. Role-playing and Debates: A simple definition of role-playing is a loose simulation in which students assume the roles of individuals or groups in a real-life situation [13]. Contemporary issues in the social sciences are often appropriate for these kinds of simulations (Examples are the placement of a toxic-waste dump, the forced integration of an ethnic neighborhood, and the opening of a nuclear power plant). In order to plan such an exercise, the instructor must clearly identify the situation, define the roles of the interest groups involved, and specify the task for each group. These proposals will inevitably conflict ideologically, tactically, economically, regionally, or in some other fundamental way. The class usually begins with a mini-lecture to establish the context and setting, after which students work on their proposals in their assigned groups. When they have finished, the instructor can hear the proposals and immediately incorporate them into a lecture on how closely they reflect positions people have taken in these conflicts (and the implications for society).

\subsection{Reading and Writing Exercises}

In-class reading and writing exercises also promote student engagement in the learning process in large classes. Class exercises can be used to gauge student learning, to help students think more deeply about the course material, and prompt class discussion.

2.4.1. Close Reading: A time-honored technique that improves reading comprehension and provides a measure of engagement in the subject matter is the Close Reading Method [7]. In class, the instructor models how to read and interpret a passage while the students follow in their books. After this demonstration, individual students may be called upon to read aloud and interpret similar selections. In a literature course, after reading particularly ambiguous passages of a novel or poem, students might be asked to 
discuss them in groups of two or three to decide what the selection means, paraphrasing it in their own words. The instructor can ask a few of the groups to give their interpretations before providing his or her own analysis. This technique works well for other kinds of analysis and interpretation. For example, teaching students to read a supply and demand curve in an economics course and reading an artifact in anthropology course. Finally, the technique can be used early in the semester in an introductory course to demonstrate how to read and highlight the textbook or the course readings.

2.4.2. Classroom Assessment Techniques: Some instructors use short, in-class writing assignments as a means to keep students mentally engaged in the course material and also as feedback to assess the extent to which students understanding the material $[17,18]$. Writing also helps them learn to express their thoughts more clearly and focuses their attention on important elements of the course. Short writing assignments (a paragraph or two) can be given as pre- and post-lecture activities. Requiring students to write their thoughts or questions about the day's topic before the lecture begins will concentrate their attention on the topic and prepare them for active listening. At the end of the presentation, writing out their impressions of the lecture, and any questions they have about the topic will help them place the material in context. It also provides valuable feedback to the instructor as a collection of possible test questions.

Students can be asked to write short summaries of material at any point during a lecture. In summarizing, they select the most pertinent elements from the material and restate them in their own words. This process of synthesis and personalization leads to better, more permanent learning. One math instructor at FEATI University which she has introduced a new concept or procedure, always ends by asking students to write a brief summary of it (e.g., how to solve a rational expression) [19,20]. Students also can describe the aspect of the material for the day they find most confusing. These "muddiest point" papers are an excellent method to determine what, if any, of the material is particularly confusing to the student.

\section{Methods and Materials}

The samples were two classes of level 2 architecture students enrolled at Qassim University in second semester, school year 2012-2013. One was the experimental group, and the other, the control group. Both groups consisted of thirty architecture students. The two groups were compared based on their final grades in Eng 104-Critical Thinking course to see to it that they had equivalent abilities. The same teacher taught them Eng 106-Expository Reading and Writing course.

To foster group interaction, the class of 30 architecture students was divided in to 3 smaller groups with 10 students in each group. This arrangement gave them a chance to interact verbally, compare and share their individual answers, and finally come up with a revised output to be submitted to the teacher. The teacher assisted them in any difficulty encountered during the interaction. Class discussion and evaluation followed.

In the control group, the same guide questions were given as assignments to be answered at home. Class discussion was conducted the following day during the usual lecture type activity.

The content of the lesson activities was the same for both the experimental and control groups, differing only in the kind of strategy used. The teacher himself prepared all the guide questions. Table 1 and 2 show the differences in the activities and the features of the classes 
under Study Group Activity Guide (SGAG) and the traditional lecture discussion method.

Table 1. Comparison of the Steps of Study Group Activity Guide and Traditional Method

\begin{tabular}{|l|l|}
\hline \multicolumn{1}{|c|}{$\begin{array}{c}\text { Study Group Activity Guide } \\
\text { (Experimentation) }\end{array}$} & \multicolumn{1}{c|}{$\begin{array}{c}\text { Traditional Method } \\
\text { (Control) }\end{array}$} \\
\hline A. Motivation (5 minutes) & A. Motivation (5 minutes) \\
\hline $\begin{array}{l}\text { B. Individual Activity ( 15 minutes) } \\
\text { Individual students given time to study by } \\
\text { themselves ensuring individual accountability }\end{array}$ & B. Class Activity (25 minutes) \\
\hline $\begin{array}{l}\text { C. Group Activity (25 minutes) } \\
\text { Cooperative Learning. } \\
\text { Sharing ideas and feelings. } \\
\text { Reward system designed not only for } \\
\text { individual but for group performance as well. }\end{array}$ & $\begin{array}{l}\text { (No intervention was } \\
\text { undertaken) }\end{array}$ \\
\hline D. Class Discussion (25 minutes) & $\begin{array}{l}\text { C. Class Discussion (25 } \\
\text { minutes) }\end{array}$ \\
\hline E. Evaluation (5 minutes) & D. Evaluation (5 minutes) \\
\hline F. Assignment (5 minutes) & E. Assignment (5 minutes) \\
\hline
\end{tabular}

\section{Table 2. Differences in Features between the Experimental and Control} Group

\begin{tabular}{|l|l|}
\hline \multicolumn{1}{|c|}{$\begin{array}{c}\text { Study Group Activity Guide } \\
\text { (Experimentation) }\end{array}$} & \multicolumn{1}{c|}{$\begin{array}{c}\text { Traditional Method } \\
\text { (Control) }\end{array}$} \\
\hline $\begin{array}{l}\text { 1. Students are given all the chances to work out what } \\
\text { is assigned to them and have things cleared out or } \\
\text { clarified if they encounter difficulties in the lesson }\end{array}$ & $\begin{array}{l}\text { Students may have the "take it or } \\
\text { leave it" attitude since they are not } \\
\text { compelled to do the assigned work. }\end{array}$ \\
\hline $\begin{array}{l}\text { 2. Students can express their ideas not only their } \\
\text { reading skills but also their communication skills as } \\
\text { well. }\end{array}$ & \\
\hline $\begin{array}{l}\text { 3. Individual and group cooperative learning will take } \\
\text { place. }\end{array}$ & \\
\hline $\begin{array}{l}\text { 4. Students will develop good values such as } \\
\text { cooperation, honesty and respect for others' opinion. }\end{array}$ & \\
\hline $\begin{array}{l}\text { 5. This will be a venue for the students to give their } \\
\text { best efforts for the welfare of the group. }\end{array}$ & \\
\hline $\begin{array}{l}\text { 6. There will be more member participation because of } \\
\text { the smaller composition of the group. }\end{array}$ & \\
\hline
\end{tabular}

To determine the effectiveness of the treatment, the teacher administered an achievement test in Expository Reading and Writing course before (pretest) and after (posttest) the treatment to both experimental and control group.

Moreover, architecture students were introduced to a variety of activities as an introductory work, rather a kind of a pretest and training task. Although, the researcher can't assess all learning outcomes in group work, yet, the researcher can assess students' learning by observing them and through peer evaluation. Therefore, the researcher observed and recorded what and how students do while they work together to complete a task, and taking their feedback to assess both their work and understanding.

The first activity that was introduced to the students was listening. So before turning the tape on, the researcher asked the students some warm up questions aiming at 
making them feel at ease and try to make them relate their prior knowledge with the contents of the tape they would be listening to (what is called pre-listening). The selected tape is entitled «Day by Day». It contains a variety of very interesting topics for instance as shown in Table 3

Table 3. Day by Day Activities

\begin{tabular}{|c|c|}
\hline \multirow{3}{*}{$\begin{array}{l}\text { Family photos } \\
\text { School crossing guard } \\
\text { On the subway }\end{array}$} & Father's day \\
\hline & Getting a loan \\
\hline & Thursday night \\
\hline Do it yourself & \multirow{2}{*}{$\begin{array}{l}\text { Jury duty } \\
\text { The sandstorm } \\
\text { Leaving the hospital }\end{array}$} \\
\hline \multirow[t]{2}{*}{$\begin{array}{l}\text { At the bank } \\
\text { Family night } \\
\text { Drifting a car } \\
\text { A visit to the dentist }\end{array}$} & \\
\hline & The academic scholar \\
\hline
\end{tabular}

While students were listening to the tape, the researcher used pauses and told the ones working in small groups that every student will be asked to respond. This leads all the members of the group to listen attentively and carefully, since they are asked to fill some blanks and answer some listening comprehension questions. According to the results obtained, the researcher noticed that students when working in small groups were unaccustomed in sharing their work with their peers. This is quite clear, because students used to be rewarded for individual efforts, and collaboration may not come naturally or easily for everyone in the starting activity. However, they almost find that working in groups, as lively and innovating. Their participation varied between low, medium and rarely high depending on student's understanding. Students were listening attentively, yet some of them did not participate in classroom mainly those shy, reticent ones. The obtained average in this activity is 13.01, which is considered as a good starting. After listening and filling the required blanks, the researcher asked the students to take roles in what they have been listening to in a form of a conversation.

\section{Results and Discussion}

Table 4 shows the results of the test of difference between the pretest and posttest scores of the experimental and control groups.

The posttest mean score of the experimental group $(\ddot{x}=30.33)$ was higher than that of the control group ( $\ddot{x}=28.03)$. The difference was found to be highly significance $(p \leq 7.14)$.

As regards the pretest results of the two groups, the control group exhibited a higher rank $(\ddot{\mathrm{x}}=11.95)$ but non-significant mean score than the experimental group $(\ddot{\mathrm{x}}=11.85)$. This suggests that the two groups were comparable before the treatment. It should be noted, though that in both groups there were increases from pretest to posttest at significant levels $(t=21.47$ for experimental group; $\mathrm{t}=6.59$ for the control group). 
Table 4. Test of Differences between the Pretest, and Posttest Scores of the Experimental and Control Group

\begin{tabular}{|l|c|c|c|c|}
\hline \multirow{2}{*}{ Group } & \multicolumn{2}{|c|}{ Mean Score } & \multirow{2}{*}{ Difference } & \multirow{2}{*}{ t-ratio } \\
\cline { 2 - 3 } & Pretest & Posttest & & \\
\hline Experimental $(\mathrm{N}=30)$ & 11.85 & 30.33 & 18.48 & $21.4746^{* *}$ \\
\hline Control $(\mathrm{N}=30)$ & 11.95 & 28.03 & 16.08 & $6.589^{* *}$ \\
\hline Difference & -0.10 & 2.30 & 2.40 & $7.14^{*}$ \\
\hline
\end{tabular}

* Significant at the $5 \%$ level of significance

** Significant at the $1 \%$ level of significance

Moreover, many architecture students who are almost unable to communicate orally in the target language and are extremely uncomfortable when are trying to speak. They also understand very little of what researcher say to them during classroom explanations and directions.

One of the most positive results that emerged from group work learning was that students created a friendly, safe atmosphere; which enabled them to freely express their ideas and opinions orally.

Furthermore, reticent, shy students, who rarely participated in classroom, often feel more confident in expressing themselves in front of the entire class after they have already practiced, expressed and discussed their opinions in their safer and smaller audience.

\section{Conclusion}

The results of the study show that architecture students, given opportunity to learn Expository and Reading lesson by exposing them to several learning experiences can improve their performance.

Collaborative learning fosters the development of critical thinking through discussion, clarification of ideas, and evaluation of others' ideas. However, both methods of instruction were found to be equally effective in gaining factual knowledge. Therefore, if the purpose of instruction is to enhance critical thinking and problem solving skills, then collaborative learning is more beneficial. For collaborative learning to be effective, the instructor must view teaching as a process of developing and enhancing students' ability to learn. The instructor's role is not to transmit information, but to serve as a facilitator for learning. This involves creating and managing meaningful learning experiences and stimulating students' thinking through real world problems. The findings showed that the experimental method of applying group work as a teaching technique is likely to result in the cooperation and good performance in students' speaking.

Students, when working in small groups, create an intimate atmosphere; where they could share ideas, exchange information, encourage each other and above all learn from each other since each student provides at least a positive contribution. All these factors may enhance students' thinking, better performance and achievements.

Other evidence of the superiority of the experimental method was observed in classroom. The experimental group was better organized and exhibited much more cooperation, motivation and increased classroom participation than those of the control group who tend to be isolated and rarely provide some classroom participation and contribution in discussions.

The value of this study is to show how students can achieve and obtain better results when collaborating together; creating an intimate atmosphere in which they freely express themselves, especially those shy students who find greater difficulties when interrogated by 
their teachers or simply by one of their classmates. They feel frustrated and unable to do like other students do and this is mainly due to their cultural backgrounds.

Hence, working in groups may be also of paramount importance for those poor or less able students because it enables them to work and even participate in classroom, become motivated and eager to learn.

Moreover, the three learning experiences encountered by architecture students in study group activity guide strategy which enhanced retention are individual activity, group activity and finally, group discussion. However, it should be noted that this strategy is tedious and time consuming. This possesses a great challenge to the teacher to plan classroom interaction well.

Actively engaging students in the classroom will help them think more deeply about the course content, bring additional energy to the classroom, and help identify the extent to which they may be struggling with the material.

\section{References}

[1] T. U. Ganiron Jr, "Student Competencies in Structural Engineering: Modeling Cultural Environment in Qassim University", Proceedings of the 40th Annual Conference of the European Society for Engineering Education, Thessaloniki, Greece, (2012) September 23-26.

[2] P. J. Frederick, "Engaging Students actively in Large Lecture Settings", Engaging Large Classes: Strategies and Techniques for College Faculty, Anker Publishing Company, Bolton, (2002).

[3] T. U. Ganiron Jr, "Cultural Learning Environment and Perception of Structural Engineering Classes in Qassim University", Transactions on Advances in Engineering Education, World Scientific and Engineering Academy and Society, vol. 9, no. 3, (2012) December 1, pp. 84-93.

[4] T. U. Ganiron Jr, “Accelerated Learning Techniques: Teaching Critical Thinking in Qassim University", Journal of Proceedings of the $41^{\text {st }}$ Annual Conference of the European Society for Engineering Education, Leuven, Belgium, (2013) September 16-20.

[5] R. B. Barr and J. Tagg, "From Teaching to Learning: A New Paradigm for Undergraduate Education", Change, vol. 27, no. 6, (1995).

[6] I. W. Anderson and D. R. Krathwohl, "A Taxonomy for Learning, Teaching, and Assessing: A Revision of Bloom's Taxonomy of Educational Objectives, New York, (2001).

[7] T. U. Ganiron Jr, "Social Capital and Career Success of Civil Engineers towards Designing Career Paths", Procedia-Social and Behavioural Sciences, vol. 102, (2013) November, pp. 611-621.

[8] I. Beatty and W. Gerace, "Technology-Enhanced Formative Assessment: A research Based Pedagogy for Teaching Science with Classroom Response Technology”, Journal of Science Education and Technology, vol.18, no. 2, (2009).

[9] T. U. Ganiron Jr and D. Tesoro, "Investigation of the Predictors of Civil Engineer Career Success", Proceedings of the 41st Annual Conference of the European Society for Engineering Education, Leuven, Belgium, (2013) September 16-20.

[10] J. M. Braxton and W. A. Jones, "The Role of Active Learning in College Persistence", New Directions for Teaching and Learning, vol. 115, (2008), pp. 71-83.

[11] C. Fies and J. Marshall, "The C3 framework: Evaluating Classroom Response System Interactions in University Classrooms", Journal of Science Education and Technology, vol. 17, no. 5, (2008), pp. 483-499.

[12] T. U. Ganiron Jr, "Human Capital and Career Success of Structural Engineers towards Designing a Career Planning Model", Journal of Proceedings of the International Conference on Industrial Technology and Management, Phuket, Thailand, vol. 49, no. 1, (2012) September 1-2, pp. 1-5.

[13] W. J. McKeachie, "McKeachie's Teaching Tips: Strategies, Research, and Theory for College and University Teachers", $12^{\text {th }}$ ed., Houghton Mifflin, Boston, (2006).

[14] T. U. Ganiron Jr, T. U. Ganiron 111 and T. U. Ganiron 111, "Modeling the Level of Objective \& Subjective Career Success of Civil Engineers towards Developing a Career Planning Program", Journal of Proceedings of the International Conference on Information and Knowledge Management, Kuala Lumpur, Malaysia, vol. 45, no. 1, (2012), pp. 36-41.

[15] T. U. Ganiron Jr and T. M. Ganiron, "Managing Career Success of Geodetic Engineers", International Journal of Education and Learning, vol. 2, no. 1, (2013) March, pp. 13-24.

[16] T. U. Ganiron Jr and A. Alaboodi, "Cultural Learning Environment in Structural Engineering Courses of Architecture and Civil Engineering Students in Qassim University", Procedia-Social and Behavioural Sciences, vol. 102, (2013) November, pp. 300-310. 
[17] T. U. Ganiron Jr and T. M. Ganiron, "Social Capital on Civil Engineer Career Success”, International Journal of Innovation, Management and Technology, vol. 3, no. 6, (2012), pp. 718-724.

[18] T. U. Ganiron Jr, "Web-Enhanced Project Management Course", International Journal of u- and e- Service, Science and Technology, vol. 6, no. 1, (2013), pp. 49-59.

[19] T. U. Ganiron Jr, "Application of Accelerated Learning in Teaching Environmental Control System in Qassim University”, International Journal of Education and Learning, vol. 2, no. 2, (2013), pp. 27-38.

[20] T. U. Ganiron Jr and A. Alaboodi, "Designing and Developing Web Enhanced Project Management Course for Engineering Graduating Students", Journal of Proceedings of the International Forum on Engineering Education, University of Sharjah, United Arab Emirates, (2010) November 23-25, pp. 173-181.

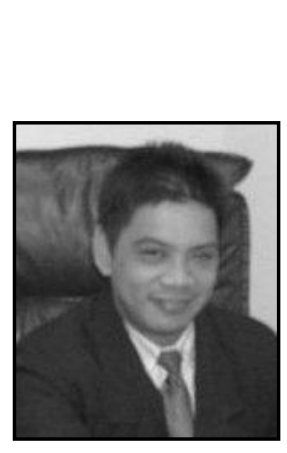

\section{Author}

Dr. Tomas U. Ganiron Jr, This author obtained his Doctor of Philosophy in Construction Management at Adamson University (Philippines) in 2006, and subsequently earned his Master of Civil Engineering major in Highway and Transportation Engineering at Dela Salle University-Manila (Philippines) in 1997 and received Bachelor of Science in Civil Engineering major in Structural Engineering at University of the East (Philippines) in 1990. He is a registered Civil Engineer in the Philippines and Professional Engineer in New Zealand. His main areas of research interest are construction engineering, construction management, project management and recycled waste materials. He has been the resource person in various seminars in New Zealand (like in Auckland University of Technology, University of Auckland and University of Canterbury). He was connected with Advanced Pipeline System in New Zealand as Construction Manager wherein he supervised the sewerage and waterworks projects. He was the former Department Head of Civil Engineering in FEATI University (Manila) and former Department Head of Physics in Emilio Aguinaldo College (Manila). He is also very active in other professional groups like Railway Technical Society of Australasia and Australian Institute of Geoscientists where he became committee of Scientific Research. He has received the Outstanding Civil Engineer in the field of Education given by the Philippine Media Association Inc. (1996), ASTM Award CA Hogentogler (2008) by IPENZ in New Zealand and Outstanding Researcher (2013) in Qassim University, Buraidah City. 
International Journal of Education and Learning Vol. 3, No. 1 (2014) 